Vol. XXV No $1 \quad 2019$

\title{
PROMOTION OF THE MILITARY PROFESSION, RECRUITMENT AND SELECTION OF CANDIDATES. CONCEPTUAL DELIMITATIONS
}

\author{
Aurelia Teodora DRĂGHICI*, Adina Eleonora SPÎNU** \\ *“Nicolae Bălcescu" Land Forces Academy, Sibiu, Romania \\ **“Aurel Vlaicu" University, Arad, Romania \\ teodora24a@yahoo.com, adinasturz@gmail.com
}

\begin{abstract}
Romania's security interests and objectives, the army missions in the current geopolitical context and Romania's obligations as a member of NATO have imposed the continuation of the process of quantitative and qualitative restructuring of the human resources and determined the decision to renounce compulsory military service in favor of the one based on volunteering, starting with the first of January of 2007. The transition from the army based on compulsory military service to the one based on voluntary service imposed the repositioning of the military profession on the Romanian labor market, especially in relation to the competition represented by other similar institutions.
\end{abstract}

Key words: military, promotion of military profession, recruitment, selection, human resources

The practice in the developed countries signals the penetration of economic logic in all sectors of social life in recent years. In this context, and in the army, any staff policy is subject to the labor market rules, accepting to compete in attracting human resources.

At the same time, the idea of the financial benefit deriving from the economic logic changes the image of the military and the motivation for the military career. Instead of the body spirit stemming from tradition, national customs and even nationalism, there emerges the idea of the professional, the citizen of the civil society, motivated by an appropriate salary [1].

\section{Promotion of the military profession} "Promoting the military profession is a component of marketing and represents all the actions undertaken and the means used to valorize the military profession, using those channels of information and messages considered to be the most appropriate for the profile of the target groups of recruiting in order to attract and increase the interest of a greater number of young people for the military profession" [2].

First of all, we note that in this definitive vision, the author circumscribes promotion strictly as a component of the recruitment marketing, which in turn "represents the totality of the activities and techniques used by an organization in order to increase/maintain the number and quality of its staff and to satisfy the expectations of potential candidates for vacant positions" [2].

There are, however, other connotations, such as the one in which promotion is understood as a "complex communication program, using a combination of various techniques and actions of information and persuasion; communication is not only 
information, but also influence, i.e. the generation of a certain behavior, attitude or action"[3.]

Moreover, the Reference Strategy states: "The promotion campaign is more and more like a psychological warfare, because, ultimately, it uses methods to influence the target audience in order to get a certain answer. The winner is the one who delivered the right message through the most effective means at the right time"[3].

With this latter comparability we cannot agree, for any of the following reasons:

- For those familiar with the environment of national defense system and national security, it is known that a psychological warfare also includes not just "Orthodox" elements, as long as they appeal, from the strict logic of gain, to the detriment of the adverse side, to manipulative methods and techniques, even in particular cases, to "brainwashing." Or the target groups must be fully aware of what they are going to assume and their firm attitudes should not be controlled, often fully justified, by artificially created initial question marks, and then through successive feedings with arguments, persuasive types, not always preferable, at least in relation to some potential candidates, who, once entered the system, realize that their place is not there;

- The second counter-argument - In the conditions of "psychological warfare" we can invoke and retain the existence of the legal imperative of fair and inter institutional competition, at least from the school environment? We think not.

In other respects, we note the critical aspect in both the above-mentioned definitions, in the way that their promoters address only "target groups" and "target audiences", completely eluding addressability to "support groups" (school, family, press, etc.). In our opinion, it is precisely the increased emphasis on the activities of promoting the military profession towards such support groups is what makes them more specific, to a greater extent, than the recruitment and selection activities, which prevail only for the target groups.

At the same time, we cannot agree, under the above conditions, and not only, with the meaning given to the notion of derecruitment in the sense that it "means the entire process of promoting the military profession, information, processing and selection of candidates. In fact, attraction and selection are factors of the recruitment process"[4]. In our view, such assertions are likely to create confusion, including among politicians directly responsible for implementation, not to mention that performance indicators cannot be introduced for periodic evaluations, which are reported in each of the three dimensions of the targeted system promotion, recruitment, selection.

Moreover, to a great extent, the methodologies, methods and techniques to be used differ, for each stage.

On the basis of all the above, regarding us, and using the above-mentioned definitive valences, by promoting the military profession we understand the set of concepts, strategies, policies, activities, measures and actions as well as specific means, methods and techniques, aimed at transmitting/receiving, in the Romanian Armed Forces system, in its internal and, in particular, external dynamics of consistent and reliable information and messages about the professional military career, with its strengths and risk factors, to/from the target groups and support groups in order to strengthen the motivations and interests of young people to take up and pursue a career as well as to maintain and develop more generally the trust and good image of the Romanian Army in the public opinion. 


\section{Recruitment of military human resources}

For Donald Currie, recruitment is a separate function, which "begins when a post has been identified and ends when a list of candidates could have been made up of job applications resulting from the disclosure of the existence of the job vacancy"[5].

On some of these nuances, we express our opinion that they are reductionist in the sense that they treat recruitment only by strictly referring to vacancies or to the new ones created at a given time. However, it is known that the recruitment also targets the candidates waiting for the expected curriculum of some organizations (institutions) such as the Ministry of National Defense, and not only.

Moreover, there is also the modern and contemporary practice of some private sector managers recruiting young middle school students, especially high school students, who after selection are provided, entirely or partially, with subsidies for tuition fees, under strictly defined conditions, in order to cover the needs of future employees, educated and trained, with multiple professional and transversal competences, needed for their own institutional development.

At the same time, some managers engage in a conjugated-conscious action with the educational factors in the practice of some people's internship, and then, after completing the studies, they actually do their selection and employment, or most of them.

In conclusion, recruitment can also be made for future posts necessary in the medium and long term.

The recruitment of human resources for the needs of the army is a topical subject in the theory and practice of the human resources management of the defense, given the new security environment developed after the end of the Cold War and the review of the national defense issue. The new NATO membership led to the abandonment of compulsory military service and the introduction of volunteering, which forced the military organization to review the recruitment process of human resources.

Volunteering is the method based on the free choice of the citizen to do or not to do the military service. Thus, the Romanian Armed Forces joined the NATO member states, which set up their exclusive volunteer army, including the United States, Great Britain, the Netherlands, France and Luxembourg.

At the level of the Romanian Army, a recruitment and selection system of professional military personnel is organized hierarchically on two levels: management (central) and execution (in the territory).

\section{Selection of the Army's human resources}

Selection should be regarded as a two-way communication process. The organization is usually in front of the people about whom they do not have a lot of information (other than that in the application form, which can be distorted). Because of this, the organization needs a minimum of information about that person before going through the selection process. According to the managerial theory and practice in the human resources field, the personnel selection process takes place in several stages, as follows:

- preliminary selection of applicants;

- filling in the application form;

- interviewing for employment;

- testing for employment;

- checking the references;

- medical examination;

- the final interview;

- the employment decision;

- installation on the post.

At the level of the Romanian Army, the candidates' files are drawn up by the information and recruitment offices. After 
completing these, they are submitted for approval to the Human Resources Management Department. The enrolled files are sent to the selection and orientation centers. The selection tryouts for these candidates take place in the selection and orientation centers, and copies of the certificates with the final selection results are submitted to the Human Resources Management Division.

The selection of human resources at the level of the Romanian Armed Forces is carried out on the basis of testing tools that ensure the identification of skills and potential for the military career, with emphasis on the qualities of military leadership.

The selection of candidates (young boys and girls) recruited by the information and recruitment offices is organized and carried out in the selection and orientation centers of Alba-Iulia, Breaza and Câmpulung Moldovenesc, according to a program, and consists of:

- psychological testing;

- medical examination;

- sports test - testing the physical potential.

The testing of the physical potential of candidates recruited for admission to military education is carried out in the selection and orientation centers. Physical potential testing is only carried out by candidates who have the medical examination performed, with the "fit for exercise" specification. Testing of the recruited candidates comprises two tryouts: the utilitarian-applicative route and the running on the $1000 / 2000 \mathrm{~m}$ distance.

- Final evaluation interview

G. A. Cole [6] considers that the selection interview can get maximum returns when the interviewer wishes to assess the candidate's motivation to fill the job, how well the candidate will fit in the team to be part of, etc.

The selection interviews must be well structured, i.e. include a predetermined set of behavioral and situational questions formulated to make it easier to highlight the degree to which candidates have the skills and competencies sought.

All these tests are eliminatory,
conditioning the participation on
admission.

- $\quad$ Testing the theoretical knowledge.

The military institution must pay particular attention to the selection process at all levels, especially for volunteer soldiers and sergeants, who are at the basis of the military hierarchy and represent the main source of the NCOs and warrant officers.

Conclusions: The recruitment and selection of professional military personnel has become more and more difficult in the conditions of the transition of the Romanian economy towards a market economy, the erosion of traditional values (patriotism, the pride of the country) and economic development. The decreasing birth rates and aging population, the youth's reduced appetite for education, as well as the existence of tempting offers on the civilian labor market direct the military institutions to highly skilled and more expensive professional work to ensure the necessary personnel of the army. Thus, the army extended its recruitment and selection environments to other "target populations", such as women, immigrants, ethnic minority groups, and young people with low levels of education who were not considered before volunteering.

\section{References}

[1] M.B. Alexandrescu, De la conscripție la marketingul recrutării și selecției resurselor umane în armata română, în Perspective ale securității și apărării în Europa, "Carol I" National Defence University Publishing House, Bucharest, 2009. 
[2] Counselor Valentina Agulescu, Concepția privind sistemul de promovare a profesiei militare, recrutare şi selecţie a personalului military profesionalizat, pe timp de pace, draft of Order of the Ministry of Defence, Not classified, 2011, p.14.

[3] Strategia de promovare a profesiei militare (2011-2015), Human Resources Management Directorate Publishing House, Bucharest, 2011, p. 8.

[4] Concepţia privind sistemul de promovare a profesiei militare, recrutare şi selecţie a personalului military profesionalizat, pe timp de pace, p.15.

[5] Donald Currie, Introducere in managementul resurselor umane, Editura Codecs, București, 2009, pp. 109-110.

[6] Cole G.A., Managementul personalului, Codecs Publishing House, Bucharest, 2005, p. 213. 